\title{
Fiscalidad regia y génesis del Estado en la Corona de Castilla (1252-1504)
}

\author{
Miguel Ángel ladero Quesada *
}

1. PODER MONÁRQUICO Y TRANSFORMACINES FISCALES. LA DINAMICA BAJOMEDIEVAL. 1252-1504.

1.1. 1265-1325: tiempos de transición.

1.2. 1325-1350: fortalecimiento del poder real.

1.3. La segunda mitad del siglo XIV: la consolidación institucional.

1.4. El siglo Xv: la conquista del poder por la nobleza y el desgaste del sistema.

1.5. Los Reyes Católicos: restauración y renovación.

2. ALGUNOS ASPECTOS DE LA POLITICA ECONÓMICA.

2.1. La regulación del tráfico y comercio de productos.

2.2. La política monetaria.

3. LOS INGRESOS. SUS CATEGORIAS Y EVOLUCIÓN.

3.1. Tipología de los ingresos.

3.2. 1265 a 1368: un siglo sin cifras.

3.3. Los primeros reyes de la Casa de Trastámara: 1369 a 1406.

3.4. El siglo XV: 1407 a 1504.

4. DIFERENTES CATEGORIAS DE GASTOS.

4.1. Antes de 1369.

4.2. La época trastámara.

5. LA ADMINISTRACIÓN HACENDÍSTICA. GEOGRAFIA FISCAL.

5.1. La administración hacendística.

5.2. Geografía fiscal.

\footnotetext{
* Catedrático de H. ${ }^{a}$ Medieval. Universidad Complutense. Madrid.
} 
6. “SOCIEDAD POLITICA» Y FISCALIDAD.

6.1. La nobleza.

6.2. El clero.

6.3. Las aristocracias ciudadanas.

\section{PODER MONÁRQUICO Y TRANSFORMACIONES FISCALES}

Nuestro trabajo se refiere a la evolución de la fiscalidad regia en la Corona de Castilla desde Alfonso X, a mediados del siglo XIII, hasta los Reyes Católicos, a comienzos del XVI, es decir, al tiempo de la Baja Edad Media, considerada aquí como época de génesis y organización del nuevo sistema político castellano.

Es preciso, ante todo, poner en relación la dinámica bajomedieval del poder monárquico con las transformaciones fiscales, admitiendo la hipótesis de que, entre Alfonso $X$ y los Reyes Católicos hay un tiempo histórico homogéneo durante el que se han puesto las bases y se han desarrollado los elementos doctrinales e institucionales de un poder político regio que hoy llamaríamos estatal - considerando al Estado como forma política no de una manera fija, o tal como hoy es, sino como un proceso de construcción a lo largo de varios siglos-, y se ha producido una relación de fuerzas entre monarquía y "sociedad política" que favoreció y permitió tanto el desarrollo del absolutismo regio como la consolidación del poder social - y de la participación política- de la alta nobleza señorial y de la pequeña aristocracia urbana, que se renuevan y desarrollan ampliamente durante la Baja Edad Media.

En una primera época, entre 1265 y 1275, Alfonso $X$ puso las bases de la nueva fiscalidad, al crear los "servicios" extraordinarios otorgados por las Cortes, imponer al ganado trashumante, organizar el régimen aduanero, aumentar las contribuciones directas de los judíos del reino, y tomar habitualmente partes de la renta eclesiástica, con licencia pontificia (tercias reales, décimas o subsidios del clero), pero su obra hubo de sufrir el contragolpe de las resistencias puestas por el reino en las Cortes, y de los abusos y anarquía nobiliaria durante los años 1282 a 1325, debidos en parte a los desajustes que las nuevas formas de percepción y distribución de renta generaban. Sin embargo, la obra alfonsina sobrevivió y, en una segunda época, Alfonso XI pudo completarla, a partir de 1338, al reorganizar la renta de la sal, el impuesto sobre el ganado trashumante (servicio y montazgo), y establecer un impuesto general in- 
directo sobre la compraventa y consumo de bienes llamado alcabala, que se convertiría en el recurso principal de la fiscalidad regia, desde 1342. Al principio era una contribución extraordinaria, que había de ser aprobada y otorgada por las Cortes.

Durante la tercera época -1369 a 1406- no aparecen nuevos impuestos, de modo que el cuadro fiscal está completo, pero maduran las instituciones de gestión hacendística, antes mucho más imperfectas o inexistentes -así, las Contadurías Mayores, o el régimen de arrendamiento de rentas-, se regulariza el pago o distribución de renta monárquica entre la nobleza, a lo que se añade el aumento continuo de las concesiones de señoríos, y crece desmesuradamente la presión fiscal con motivo de las guerras y compromisos exteriores de Enrique II y Juan I. Algo antes del año 1400, la alcabala pasa a ser una renta ordinaria, lo que significa un aumento claro de la independencia de la monarquía con respecto a las Cortes.

Este cuadro de auge y consolidación del poder «estatal» monárquico se ve matizado, e incluso comprometido, entre 1407 y 1474: observamos en esos decenios un desgaste del sistema hacendístico, debido a la ocupación por la alta nobleza de partes de cada vez mayores de la renta monárquica. Pero fue también entonces cuando llegó a su perfección la legislación hacendística, que apenas se modificaría en los dos siglos siguientes, mientras que, además, la presión fiscal tendía a disminuir en una Castilla en proceso de fuerte crecimiento demográfico y económico.

Por úitimo, en la época de los Reyes Católicos, se consiguió restaurar y renovar el funcionamiento del sistema hacendístico: en el primer aspecto porque se rescató una gran cantidad de rentas reales enajenadas, y se mejoraron los procedimientos de cobro. $Y$, en el segundo, porque los reyes aumentaron las rentas extraordinarias, y diversificaron sus orígenes. No obstante, el nivel total de los ingresos de la Hacienda real en 1504 no era superior al que había alcanzado hacia 1400, después del gran aumento del último tercio del siglo XIV, aunque la población de la Corona de Castilla se había multiplicado por dos, seguramente, a lo largo del siglo XV.

\section{ALGUNOS ASPECTOS DE LA POLITIICA ECONÓMICA}

Hay que relacionar algunos aspectos de la política económica bajomedieval con el hecho evidente de que la renovación del sistema hacen- 
dístico se basa en el gran desarrollo de la actividad mercantil, y en la expansión de la masa monetaria hasta penetrar en todos los aspectos de la vida económica. Los impuestos indirectos proporcionan más del 90 por 100 de los ingresos ordinarios de la monarquía desde mediados del siglo XIV, mientras que los directos, aunque importantes, mantienen un carácter eventual y extraordinario.

Por lo tanto, es interesante conocer cómo los monarcas, utilizando su poder regaliano, han protegido y estimulado el tráfico y comercio, tanto en el interior del Reino como en sus relaciones exteriores. Alfonso $\mathrm{X}$, al tiempo que organizaba las aduanas, legisló sobre la forma del comercio exterior y las "cosas vedadas» -metales preciosos, cereales, ganados, caballerías, productos estratégicos-, así como sobre las licencias para exportarlas. Este mismo monarca insistió en la libertad de tráfico interior, en especial de los cereales, y consolidó la política de creación de ferias que venía desarrollándose desde mediados del siglo XII. En una primera fase de expansión económica, entre dicho momento y comienzos del XIV, se fundaron más de 50 ferias, casi todas en territorio «realengo». En una segunda, a lo largo del siglo XV, predominó la fundación de ferias rurales, muchas de ellas en señoríos, de algunas ferias y muchos mercados semanales urbanos, y de una gran feria general, la de Medina del Campo, que actuó también como centro regulador de pagos. Todo ello muestra la madurez y generalidad de la red mercantil casiellana.

La política monetaria de los reyes castellanos se conoce hoy en sus grandes líneas a partir también de la época de Alfonso $X$, que conservó una buena moneda de oro de tipo musulmán, la «dobla» de 4,6 $\mathrm{g}$ pero no pudo mantener una moneda de plata y de vellón estable, sino que devaluó la moneda de vellón en tres ocasiones desde 1266 a 1277. Ahora bien, en Castilla, la moneda de cuenta, que es el "maravedí» desde tiempos del Rey Sabio, fluctúa junto con la moneda de vellón, que además suele estar sobrevaluada en su curso legal con respecto a la plata que contiene, que es cada vez menos, de modo que el nominal de las monedas de oro y plata, expresado en maravedíes, sube mucho durante la baja Edad Media, y también los precios de los bienes, servicios y rentas en maravedíes, pero es necesario deflactarlos para conocer su evolución auténtica, en oro o plata, y tener en cuenta también que la «ratio» entre estos dos metales no es fija a lo largo de aquellos dos siglos y medio.

Respecto a los tipos monetarios, hay que señalar la aparición de una nueva moneda de plata muy estable, desde el reinado de Pedrol, el «real», que viene a añadirse a la dobla de oro como pieza de gran 
circulación en Castilla. Por el contrario, el ducado comenzó a acuñarse sólo en 1497, y circuló poco en el siglo XV, pero es una moneda internacional, de modo que he hecho los cálculos de rentas reales estimando la equivalencia en cada momento de maravedies a doblas de oro y de éstas a ducados (a razón de $1 \times 1,3$ ), o bien de maravedíes a ducados directamente en el siglo $\mathrm{XV}$, cuando es posible conocer su curso legal en Castilla (Vid. nota sobre equivalencias monetarias y evolución del valor del maravedí).

La moneda de vellón más frecuente desde mediados del siglo XIV fue la «blanca», cuyo curso legal era de medio maravedí, aunque su contenido en plata solía ser menor. Debido a las devaluaciones del vellón, con momentos de «quiebra de moneda» especialmente virulentos a veces, la inflación de precios expresados en maravedies fue grande, aunque desigual según las épocas, pero se consiguió un gran aumento de la masa monetaria y mayor fluidez o velocidad de su circulación a lo largo de aquella época, lo que era indispensable para el desarrollo de la economía mercantil. $\mathrm{Y}$, también, un reforzamiento de la autoridad monárquica, que acuñaba la moneda, imponía su curso legal, y obtenía más beneficio de las devaluaciones que no otras fuerzas políticas. Por otra parte, estos procesos consolidaban la primacía de los impuestos indirectos, más flexibles al cambio, puesto que se cobraban por porcentaje. Añadamos, para concluir, el contraste entre la situación de la plata, casi siempre algo más escasa, y del oro, que fue más barato y abundante en Castilla, sobre todo en el S., que en otras partes de Europa debido al mejor aprovisionamiento a través del Islam de Occidente.

\section{LOS INGRESOS. SUS CATEGORIAS Y EVOLUCIÓN}

La tipología de los ingresos de la fiscalidad regia es algo compleja (Vid. cuadro adjunto) cuando llega a su madurez, pero su diversidad no debe ocultar la importancia desigual de unos ingresos con respecto a otros.

Los reyes de Castilla no tenían «dominio real», ni propiedades o bienes raíces apreciables que generasen renta. Desde otro punto de vista, toda la Corona de Castilla, en especial el realengo, era el «patrimonio real», pero esto no generaba, naturalmente, unas relaciones de propiedad sobre la tierra que derivaran en el pago de rentas tal como censo o arrendamiento (los impuestos directos se refieren al «dominio eminente» 
de la monarquía, de tipo político, no a la condición de propietaria de tierra). Los derechos de tipo feudal o señorial que cobraban los reyes bajomedievales eran ya muy antiguos y de poca importancia monetaria, excepto los relativos a la redención de deberes militares -fonsaderahasta mediados del siglo XIV, y fueron sustituidos, en realidad, por los servicios de las Cortes. Debemos incluir entre ellos las parias pagadas por los emires de Granada para compensar el otorgamiento de treguas y reconocer su condición de vasallos de los reyes castellanos.

No se había perdido, pues, el sentido del reino como "patrimonio real» en un sentido jurídico-público, ni tampoco el de los regalia inherentes al poder regio, y se perfiló más después de la recepción romanista. Entre las regalías fiscales contamos a la renta de salinas y venta de sal en régimen de estanco, que mantuvo siempre alguna importancia, y también a las capitaciones o «pechos» de judíos y mudéjares, considerados como parte del «tesoro real», según una vieja concepción islámica, modificada, sobre el status jurídico de las "gentes del Libro». El quinto real sobre el botín de guerra, también de origen islámico, podría incluirse entre las regalias.

Pero la base del sistema fiscal que se constituye desde tiempos de Alfonso $X$ son los impuestos indirectos. No los portazgos locales, cedidos en su mayoría a las fiscalidades de las ciudades, o a las señoriales, sino las aduanas y, desde su implantación general en 1342, la alcabala. El servicio sobre los ganados trashumantes es también un impuesto sobre el tráfico de bienes semovientes.

Respecto a las contribuciones directas, tienen muy poca importancia las antiguas o "foreras", pero son de gran valor las nuevas o "servicios" otorgados por las Cortes desde 1269: siempre tuvieron un carácter extraordinario, y su importancia relativa fue mayor, lógicamente, antes de 1342.

Los reyes de Castilla tuvieron más posibilidades que los de otros países europeos para obtener renta del clero de su país, argumentando con la condición de Castilla como país de frontera con el Islam. Algunos ingresos eclesiásticos pasaron a integrarse en las finanzas regias, también a partir de la época de Alforiso X: así, las «tercias reales" (2/9 del diezmo eclesiástico), con carácter habitual, y, con mucha frecuencia, una "décima» sobre el total de las rentas eclesiásticas, si el Papa otorgaba la licencia de cobro. Añadamos las recaudaciones por limosna para la cruzada, que se predica en diversos momentos de los siglos XIV y XV, y las rentas de las "mesas maestrales" de las Órdenes Militares de Santiago, Calatrava y Alcántara en época de los Reyes Católicos, que obtuvie- 
ron de Roma la administración de los maestrazgos. Por el contrario, durante aquel reinado, las multas y confiscaciones decretadas por la Inquisición sirvieron casi exclusivamente para financiar su propio aparato judicial y administrativo.

En algunos momentos de guerra, los reyes apelaban a los préstamos a corto plazo, aunque a veces los devolvían enajenando alguna renta o derecho, o el señorío sobre algún lugar. Pero no hay una organización de deuda pública estable hasta finales del siglo XV, a partir de 1490, cuando los Reyes Católicos empezaron a vender «juros» al 10 y luego al 7,12 por 100. El «juro» sería el gran instrumento de deuda a largo plazo de la Hacienda castellana durante los siglos XVI y XVII.

No es fácil hacer estimaciones cuantitativas sobre el total de las rentas de la Corona antes de 1369, ni cálculos sobre cada renta en particular antes de 1429. Una observación atenta de los datos disponibles permite establecer un primer nivel de ingresos, el que obtuvo Alfonso $X$ a partir de 1269 , en torno a $450.000 / 600.000$ ducados, $y$ un segundo nivel, obtenido a partir de 1342 , que sería de 650.000 a 800.000 ducados. Pero habría muchas desigualdades de un año a otro, porque casi todo dependía de los «servicios" de Cortes y de cuántas «monedas» - unidades de cobro - fuera cada uno.

Los cálculos son más sencillos entre 1369 y 1406 porque conocemos el valor exacto de cada "servicio", y hay estimaciones válidas sobre el de las rentas ordinarias. Se observa un gran aumento de la presión fiscal (mínimo de 850.000 ducados/año, máximo de 1,7 o 1,8 millones, medios de 1,2 a 1,5) sobre todo coincidiendo con las guerras que mantuvieron Enrique II y Juan I, y con las grandes quiebras monetarias que siguen a 1369 y 1386 . Por eso, la política pacífica de Enrique III fue un alivio, entre 1391 y 1395, y se aceptó más fácilmente su operación de devaluación monetaria en 1398. De hecho, fue el único rey de su dinastía que dejó un buen tesoro a su muerte, y las finanzas públicas saneadas.

Las cifras son más abundantes a medida que avanza el siglo xV. En síntesis, la evolución de los ingresos ordinarios muestra un descenso muy fuerte entre 1406 y 1474, en especial desde 1430, que obedece a razones políticas, aunque es cierto que hubo también un descenso de la presión fiscal indirecta, en especial de las alcabalas. De un índice 100 en 1406 se baja al 62,2 o 66,6 (según se refiera a oro o plata) en 1453 y al 25 o 30,5 en 1474. 
Los reyes intentaron compensar esta disminución apelando a "servicios" extraordinarios otorgados por las Cortes y cobrados por el procedimiento de «pedido y monedas", sobre todo durante las guerras contra Granada, que permitian cobrar también la cruzada y la décima sobre las rentas eclesiásticas. He aquí un cálculo aproximado para algunos momentos del siglo que comprende todos los ingresos, ordinarios y extraordinarios:

1407-1411: 1,45 millones de ducados/año.

1430-1440: 1,20 .

1444-1454: 0,80 a 0,90 .

1455-1460: 1.

1462-1474: 0,50 a 0,40 .

Los Reyes Católicos restauraron poco a poco el nivel de los ingresos ordinarios: en 1504 era aproximadamente como en 1406. Al mismo tiempo, renovaron el sistema de ingresos extraordinarios, añadieron algunos nuevos (contribuciones de la Hermandad de ciudades en los años en que no hubo servicios de Cortes. Cruzada y décima. Ordenes Militares. Venta de juros. Contribuciones extraordinarias de judíos y mudéjares) y, además, cobraron las rentas de Granada después de su conquista. Sumado todo, en 1504 el nivel de rentas reales era de 1,4 a 1,6 millones de ducados, como en los mejores momentos de un siglo atrás. Pero la población había crecido mucho, lo que indica que la presión fiscal había disminuido, y así fue efectivamente en muchos casos, o bien que una parte de las rentas generadas por el sistema fiscal monárquico no iba a parar a los reyes sino a manos de la nobleza señorial, después del proceso de desgaste ocurrido entre 1407 y 1474.

Podemos responder a otra pregunta con los datos cuantitativos de que disponemos desde 1429: ¿qué importancia relativa tenía cada renta? Entre los ingresos ordinarios, las alcabalas, arrendadas casi siempre junto con las tercias reales, proporcionaban en torno al 80 por 100 (de los que $9 / 10$ o algo más son alcabalas), mientras que las aduanas son un 12 por 100, aunque la monarquía enajenó algunas aduanas importantes después de 1465 (los diezmos de la mar de Castilla) y parece que en tiempo de los Reyes Católicos no se cobraba en el tráfico con el reino de Valencia. Las salinas y alfolíes de sal significan el 3,5 03 por 100 y el servicio y montazgo en torno al 2,5 por 100 , mientras que los demás derechos apenas suman otro 2 por 100. 
La importancia de los ingresos extraordinarios varía mucho de unos a otros años, por lo que las cifras medias tienen un valor explicativo limitado. Entre 1429 y 1454 fueron otro 50 o 60 por 100 sobre los ordinarios, pero entre 1455 y 1474 no son más de un 35 por 100, para subir de nuevo en tiempo de los Reyes Católicos hasta un 85 por 100.

\section{DIFERENTES CATEGORIAS DE GASTOS}

Respecto a los gastos y sus diferentes categorías, es evidente que la renta real se redistribuía en buena parte entre la aristocracia del reino para pagar servicios o disponibilidad militar, bien a través de sueldos (sueldo, tierra, acostamiento) o de tenencias de castillos pagadas también en dinero, en tiempo de paz, bien a través de los gastos extraordinarios que producian las guerras.

Antes de 1369 todos los ingresos extraordinarios tenían este destino, y los ordinarios - no más de un tercio del total de ingresos- se destinaban a la Casa y Corte del rey y al pago de los servicios judiciales y administrativos situados en ella.

Entre 1369 y 1504 mejoraron los procedimientos de cálculo de ingresos y gastos rápidamente. No había, por supuesto, presupuestos como los actuales, pero sí estimaciones o «apuntamientos» de los que conocemos algunos (Vid. los resúmenes de 1429 y 1504). Hay en ellos una parte de gastos producida por quiebras o premios a los participantes en las subastas de rentas (suspensiones, prometidos). Otra, importante, son mercedes que se pagaban automáticamente cada año por estar "situadas" en la contabilidad regia, lo que introduce un factor de estabilidad muy satisfactorio para los beneficiarios de las mercedes (nobles, ciudadanos, instituciones eclesiásticas): el «situado» subió de 26 por 100 a 85 por 100 de los gastos entre 1429 y 1474, para descender a 30 o 35 por 100 , como media, en época de los Reyes Católicos, que lo incrementaron sobre todo debido a la venta de "juros" en la segundad mitad del reinado, después de haber procedido a una fuerte reducción en 1480 .

Los gastos de cada año, a pagar con órdenes específicas de pago llamadas "libranzas", solían comprender en torno a un 40 por 100 de gastos militares de diverso tipo, un 10 por 100 para el gasto de la Casa y Cámara del rey, y diversas cantidades para lo que hoy llamariamos administración civil (pago de «raciones», "quitaciones", Consejo Real, 
Mayordomo, Contadores Mayores, "continos»...), y para ayuda a diversas personas e instituciones (mantenimientos ayudas de costa, limosnas), más un capítulo de importancia variable para obras públicas o en los palacios y alcázares del rey en diversas ciudades.

Las guerras y las relaciones exteriores tenían que pagarse necesariamente con ingresos extraordinarios, debido a su costo enorme. Tanto en 1406 como en 1429 se estimaba en 100 millones de maravedíes (1,3 millones de ducados) el costo de un ejército durante seis meses, para combatir en la península, que tuviera 10.000 «lanzas», 4.000 jinetes, 40.000 a 50.000 infantes, 25 a 30 galeras y 35 a 50 naos y "carracas", más artillería y pertrechos auxiliares: ésta era, seguramente, la capacidad militar máxima que podían desplegar los reyes de Castilla en sus guerras contra Granada.

Las cuentas del tesorero "de lo extraordinario» entre 1495 y 1504 son muy significativas al respecto (Vid. resumen): de 1.730 millones de maravedies (4,6 millones de ducados), el 61 por 100 son gastos de guerra, el 13,75 de diplomacia y matrimonios de infantas, más otro 13 por 100 para devolver préstamos contratados para operaciones bélicas, y otro 6,5 indeterminado pero relativo también a las relaciones exteriores de los Reyes Católicos.

\section{LA ADMINISTRACIÓN HACENDÍSTICA. GEOGRAFIA FISCAL}

Las dificultades en la elaboración del nuevo sistema de Hacienda no sólo se perciben en la continua y compleja puesta a punto del aparato tributario, que ya hemos descrito, sino también en la lentitud con que se desarrollan los aspectos de gestión institucional y elaboración de normas reguladoras, con frecuencia mediante la yuxtaposición y acumulación de elementos que no siempre eran homogéneos, pues los principios de globalización y racionalización, hoy tan elementales, no lo eran entonces.

La complejidad se observa en la misma geografía de los distritos tributarios, heterogéneos según rentas, e incluso según partes o «ramos» de la misma renta. Con frecuencia se utilizan circunscripciones eclesiásticas, municipales o señoriales, establecidas en tiempos anteriores con otros motivos.

La gestión de las rentas se rige, en cada caso, por las normas contenidas en "cuadernos" y completadas por las "condiciones" concretas establecidas para cada período recaudatorio. Los «cuadernos» más anti- 
guos corresponden a los últimos años del reinado de Alfonso $\mathrm{XI}$ y tienen un contenido casuístico y acumulativo que no desaparece en los más completos y definitivos, correspondientes a los dos últimos tercios del siglo $\mathrm{xV}$. Con todo, estos textos normativos son una fuente de conocimiento de gran importancia, y su abundancia y perfeccionamiento entre 1370 y 1460 testimonia el desarrollo del poder político del estado monárquico.

Los procedimientos de cobro de rentas y derechos eran también varios, debido a la debilidad y casi inexistencia de una burocracia regia adecuada a tales misiones y efectos. La gestión directa era, en efecto, muy escasa y desaconsejable, pues rendía mucho menos (son los períodos en que una renta está «en fieldad»). Cobrar utilizando como intermediarios en la recaudación a los poderes municipales tenía, por su parte, el inconveniente de otorgar demasiadas facultades en aquel terreno a los «patriciados urbanos", con detrimento del poder real, por una parte, y del resto de la población de «realengo», por otra, dados los abusos y desiguales tratos que podía recibir. Por eso los reyes procuraron evitar siempre aquel procedimiento, salvo para el cobro de alguna parte de los "servicios", que requerían la confección previa de padrones de vecindario, y el cobro casa por casa. A finales del siglo $x \mathrm{~V}$, en el marco de un equilibrio de fuerzas políticas muy favorable a la monarquía, accedieron los reyes desde 1495 a que los municipios gestionaran el cobro de alcabalas a través del régimen de "encabezamiento", en el que se establecía previamente la suma total a pagar a la Corona.

El procedimiento de gestión del cobro más rentable económicamente y de menor compromiso político era el arrendamiento de las rentas reales en subasta pública, por períodos cortos de uno a cinco años. El posible beneficio de los arrendadores era menor que el costo a que habría dado lugar un aparato administrativo propio de la Corona, además de que los arrendadores habían de pagar en cualquier caso y a plazos fijos, de modo que a menudo actuaban como prestamistas o proveedores de créditos a la Corona, y sus abusos eran vistos por jueces ordinarios, al ser personas privadas. Por otra parte, la legislación prohibía arrendar a determinadas personas que, por su poder regional o local, podrían distorsionar el proceso de la subasta y actuar después con prepotencia.

La figura del arrendador aparece, a menudo, rodeada de cierto halo de marginalidad social, que es compatible con la promoción económica y con el anudamiento de fuertes vínculos con los poderosos. Muchos arrendadores fueron judíos en los siglos XIII y XIV, o judeoconversos en el XV, y no sólo de rentas de la Corona, sino también eclesiásticas, señoriales y municipales, a pesar de los intentos de prohibición o limitación. Hacia 
1386 se estimaba que habria en Castilla unos 5.000 o 6.000 judíos interesados en el arrendamiento de rentas reales. Aquello fue siempre un acicate para los sentimientos y manifestaciones antijudías, aunque en el siglo XV hubiera muchos menos judíos arrendadores - pero más conversos, en cambio - y aunque bastantes "cristianos viejos" también practicaran aquella actividad.

Los reyes disponían, por lo demás, de un aparato institucional hacendístico reducido pero creado en casi todos los aspectos durante la época que ahora nos interesa. Algunos cargos de origen más antiguo conservaron importancia honorífica y algunas funciones, como el Mayordomo Mayor y el Camarero, pero el Tesorero o Almojarife Mayor, judío en muchas ocasiones, fue suprimido hacia 1379, y sustituido primero por tesoreros territoriales y, después, por diversos recaudadores y tesoreros.

Lo principal fue el nacimiento de cargos y órganos contables y censores especializados, cuya existencia comienza a percibirse desde mediados del siglo XIV, aunque su plena consolidación se debe a Enrique II, que llevó a su madurez la administración hacendística central al establecer dos Contadores Mayores de Hacienda y otros dos de Cuentas, con sus correspondientes auxiliares. Los Contadores Mayores de Hacienda se convertirían rápidamente en los principales oficiales de la Corona.

Utilizando todos aquellos procedimientos y medios se había conseguido que la capacidad de actuación de la fiscalidad monárquica fuera bastante homogénea en todo el territorio de la Corona de Castilla. No obstante, había situaciones desiguales o excepcionales todavía en el siglo $x \vee y$, por otra parte, el valor de cada región o área para la Hacienda regia era diferente e impulsaba a los reyes a ocuparse con mayor o menor intensidad de unas $u$ otras en este aspecto o, dicho de otra manera, había un grado de tolerancia diferente hacia las resistencias o las ocultaciones que se debía tanto a diferencias jurisdiccionales -salvo en algún caso- como al interés fiscal en juego o, más ampliamente, al interés político. Así se explican las exenciones de alcabala en los lugares de la frontera de Granada, o el impago consuetudinario pero abusivo de los servicios de Cortes en la Galicia del siglo xV, o las peculiaridades fiscales de Vizcaya y, en menor medida, de Guipúzcoa o Asturias, o las diversas exenciones y franquezas de personas, grupos e incluso ciudades enteras con respecto a las "monedas", que eran una parte de los servicios de Cortes. 
Respecto a la importacia tributaria de cada ámbito, es posible calcularla, entre 1429 y 1504, sobre la base del importe de las alcabalas. Partiendo de las estimaciones hechas en un trabajo anterior (Vid. anexo) es fácil deducir que el eje económico y demográfico de la Corona de Castilla se situaba en una amplia franja central NE-SO desde Burgos (Castilla Norte), pasando por Valladolid y Segovia (Castilla Sur), Toledo a Córdoba y Sevilla. Allí se concentra entre el 60 y el 65 por 100 de los ingresos.

Hay, también, dos sectores laterales de importancia similar: al E., las tierras de los obispados de Calahorra, Osma, Sigüenza, Cuenca y Cartagena, con un 13 a 16 por 100, y al O., Asturias, León y Extremadura con un 14 a 19 por 100 . Galicia forma sector por sí misma. Se constata también el desplazamiento del centro de gravedad tributario de la Corona de N. a S., a medida que avanza el siglo pues, cuando termina, el crecimiento más importante ha correspondido a Andalucía, mientras que ha decaído un poco Castilla Norte (debido en parte a la enajenación de las aduanas).

\section{6. «SOCIEDAD POLIITICA» Y FISCALIDAD}

En este apartado examinaremos las diversas relaciones político-institucionales y sociales que se establecian en torno a la fiscalidad regia y, secundariamente, en torno a otras fiscalidades peor estudiadas hasta hoy. Tendremos en cuenta las peculiaridades y diferentes actitudes de los grupos sociales que constituían la "sociedad política", únicos capaces de protagonizar el diálogo y el enfrentamiento rey/reino en torno a los límites y a la forma de ejercerse el poder monárquico.

\subsection{La nobleza}

El proyecto político nobiliario parece haber consistido en compartir y mediatizar el poder regio desde dentro del mismo. La nobleza no actúa políticamente como estamento sino más bien por medio de banderías y partidos, de modo que las tensiones entre unos nobles, o grupos de nobles, y otros son muy fuertes, y la línea política general es a veces difícil de establecer en medio de unos avatares políticos complejos, a veces de aspecto casi caótico, pero compatibles, en definitiva, con el 
fortalecimiento doctrinal e institucional de la monarquía, que favorecia también los intereses políticos nobiliarios en conjunto.

En lo que toca a los aspectos hacendísticos, cabe distinguir tres fases. Entre 1268 y 1369 el problema mayor es la insuficiencia crónica de los recursos regios y la falta de estabilidad en las formas de redistribución de esta renta, concentrada por la monarquía, bajo la forma de «tierras» y sueldos, mercedes, ayudas de costa y mantenimientos. Las luchas por el poder lo son también por obtener parcelas de renta, y así se explican mucho mejor tanto las «privanzas» de algunos nobles como las rebeldías de otros, las pugnas entre tutores, durante las minorías de Fenando IV y Alfonso Xl, las "malfetrías" —abusos, robos, expoliosque cometen los poderosos, y los intentos mismos de reacción monárquica y reorganización que emprende Alfonso $\mathrm{XI}$ desde la cuarta década del siglo XIV.

Entre 1369 y 1480 se desarrolló una sistematización mucho más perfecta del reparto de renta monárquica, a partir del triunfo de los Trastámara: ordenamiento de pago de sueldos y tierras en 1390, formación de los primeros registros de mercedes "situadas", en época de Enrique III, regularización del pago de libranzas, etc... Pero se incrementó también la importancia de los repartos entre bandos victoriosos y las confiscaciones a los vencidos, después de cada crisis - así, en 1430 y 1445-, y se agudizó el expolio de la fiscalidad monárquica durante los reinados de Juan II y Enrique IV - acuerdos y compensaciones entre nobles pagados por la Hacienda regia, más y más mercedes - hasta llegarse al borde del colapso entre 1465 y 1474 . Por otra parte, en aquel siglo aumentaron muchísimo los territorios de jurisdicción señorial, lo que supuso una merma notable para los ingresos fiscales regios. Pero, al cabo, la alta nobleza aceptó el principio de que su propio proyecto de dominio social y político sólo podía realizarse al amparo y en el seno de un Estado monárquico fuerte, libre de las tensiones a que lo sometían las banderías nobiliarias: podemos pensar que esta convicción sustenta y permite el amplio trabajo de restauración y renovación del aparato estatal monárquico que desarrollaron los Reyes Católicos y que tuvo - ya to hemos indicado- importantisimas facetas hacendísticas.

La casuística de cómo los nobles intervenían la fiscalidad regia en su beneficio es variada. Podían convertirse en beneficiarios de renta monárquica por la vía legal de las mercedes, "tierras", sueldos y otros pagos bien regulados, aunque, a veces, la tardanza en cobrar o la inestabilidad de la situación política llevaban al noble a hacer «tomas» en rentas regias a su alcance o, más simplemente, a cometer abusos y «malfetrías». A medida que se extiende el número e importancia de los 
señoríos nobiliarios, en época trastámara, los nobles procurarán que los tributos pagados por sus habitantes reviertan más en su beneficio que no en el de la monarquía, que les ha concedido tales señoríos. Lo consiguen por dos vías: una, la de retener la renta monárquica cobrada en el señorío $y$, otra, la de crear su propia fiscalidad nueva en el marco señorial.

En el primer aspecto, no es raro que el noble perturbe o bloquee el proceso de arrendamiento de rentas para alejar competidores y quedarse él con la subasta, directamente o a través de persona interpuesta, o bien que obligue al arrendador a «avenirse» con él, dándole una cantidad menor y quedando, de hecho, libre para cobrar la renta en el señorío. La batalia se libra en torno a las alcabalas y tercias, los servicios de Cortes $y$, en algunos casos, las aduanas, $y$ el triunfo de la nobleza señorial estuvo más cerca que nunca en tiempos de Enrique IV, que permitió a los señores cobrar los servicios reales en sus señoríos (así, en 14551456 , de los 87.500 .000 mrs. que importaba el servicio, 30.000 .000 los percibieron directamente diversos señores), autorizó el que las alcabalas y otras rentas reales ordinarias fueran "tasadas" en los señoríos, según cantidades globales que favorecían de por sí al noble, y que éste cobrara sobre ellas los sueldos, mercedes y otras prebendas que tuviera con cargo a la Hacienda regia y entregara al arrendador real sólo lo sobrante, si es que había, y, eri fin, el rey enajenó algunas aduanas importantes, por ejempio los «diezmos de la mar de Castilla» a favor de los Velasco, condes de Haro, en 1466, o toleró que otros nobles ocuparan ilegalmente rentas de portazgos, o el "servicio y montazgo" sobre los ganados trashumantes que pasaban por sus señorios. Los Reyes Católicos, a pesar de romper con aquella situación, tuvieron que aceptar el que algunos grandes nobles siguieran cobrando en sus señoríos las alcabalas reales.

Hay un segundo aspecto a considerar, además, y es el de la adaptación de la renta señorial a los cambios de la vida económica, en un sentido parecido al que había seguido la renta monárquica. Muchos de aquellos señoríos eran sólo de jurisdicción, y no implicaban propiedad de la tierra por el noble, de modo que las rentas «solariegas» o no existían o eran pequeñas. Por otra parte, las rentas señoriales de tipo antiguo - martiniega, yantar, monopolios señoriales, etc. - rentaban cada vez menos, igual que ocurría en el «realengo», de modo que la nobleza señorial de época trastámara se lanza a la búsqueda de nuevas fuentes de ingresos. A veces produjo ésto abusos en el seno de los señoríos: «tomas» de plata de las iglesias, cobro de derechos y rentas pertenecientes a la fiscalidad de los municipios enclavados en el señorío, abusos sobre los campesinos para favorecer $-\mathrm{y}$ pagar - a los servidores del señor, sobre todo interviniendo en matrimonios y herencias. Pero lo más general 
es que perdominen vías legales: compra de propiedades rústicas por el señor en sus mismos señoríos y mejora de las rentas agrarias correspondientes; fomentos del tráfico y comercio, mediante la promoción de ferias y mercados, y el control de caminos y puentes (portazgos, rodas, peajes, control de pesos y medidas, derivados de todo ello); participación en la actividad mercantil mediante la comercialización de sus excedentes agrarios, y acumulando propiedades o monopolios de uso de tiendas, almacenes, talleres y otros inmuebles comerciales o artesanales... uniendo estos aspectos al control de la fiscalidad regaliana en el señorío, la gran nobleza castellana del siglo $\mathrm{xV}$ no sólo no sufre los efectos de la crisis de la «renta feudal», sino que aumenta sus ingresos a medida que el siglo avanza.

Lo ejemplos conocidos permiten ilustrar estas líneas interpretativas generales. En Andalucía, los señoríos de nobleza seglar próximos a la costa atlántica proporcionaban una renta en la que más del 60 por 100 , de la cobrada en dinero, se relacionaba con actividades mercantiles, mientras que señoríos del interior en manos de Ordenes Militares, a la vez solariegos y jurisdiccionales, mantenían una «renta señorial» de características más tradicionales, en la que sólo entre 5 y un 10 por 100 de sus componentes estaban directamente relacionados con el comercio.

La procedencia de las rentas es también interesante. En los señoríos de los Zúñiga, futuros duques de Béjar, entre 1450 y 1480 , un 70 a 73 por 100 de los ingresos proceden de rentas, libranzas y mercedes situadas sobre la fiscalidad de la Corona, solo un 7 a 11 por 100 de pechos y derechos propios de la fiscalidad señorial, y entre un 11 y un 17,5 corresponden al arrendamiento de "dehesas» para pasto de gandado, propiedad de los señores. Situaciones semejantes se comprueban en los señoríos de los La Cerda, condes de Medinaceli, o de los condes de Medellín, en Extremadura. La tendencia es, por lo tanto, general y común, aunque los porcentajes pueden diferir bastante.

Gracias a todos aquellos procedimientos, la renta acumulada por la alta nobleza a comienzos del siglo XVI era tanta como la renta de que disponía la Corona. El embajador veneciano Vicente Quirini estima, hacia 1505 , que la renta del rey es de 550.000 a 600.000 ducados anuales - debe referirse a las rentas ordinarias, y a su parte disponible, una vez deducido el «situado»-, y las de la alta nobleza en su conjunto de 620.000 ducados, aunque el reparto entre las diversas casas nobles era muy desigual, pues oscilaba entre los 2.500 y 40.000 ducados anuales.

Añadiremos los datos, de la misma época, de otra fiscalidad que compartían también la Corona y los nobles, como es la de las Ordenes 
Militares de Santiago, Calatrava y Alcántara. Los Reyes Católicos administraban los maestrazgos, cuyas «mesas» en conjunto rentaban 110.000 ducados, la mayor parte de ellos invertidos o consumidos en obligaciones dentro del marco de cada Orden. La encomiendas estaban en manos de medianos y pequeños nobles -las tres Órdenes tienen en total 180 encomiendas-, y rentaban otros 125.000 ducados, pero en ellas la dependencia con respecto al rey era mayor: el cargo era como máximo vitalicio, y la designación correspondía al rey, como administrador de la Orden.

\subsection{El clero}

La relación con el alto clero se caracteriza por el apoyo bastante continuo de los obispos y demás dirigentes eclesiásticos a la política hacendística de la Corona, a cambio de la protección y defensa de su propio fuero, pero esta afirmación general requeriría la explicación de numerosos aspectos de detalle sobre los que tenemos insuficiente información. Hubo una colaboración evidente con el crecimiento del Estado monárquico, aunque no siempre sencilla ni abierta, como se muestra en la paulatina aceptación de aspectos de patronazgo regio, o en la entrega de fuentes de renta y de empréstitos muy fuertes (tercias reales, décimas y subsidios, contribuciones extraordinarias, predicación de cruzada...). Además, hay que tener siempre presente la diversidad de intereses y actitudes: Roma, por una parte, y el clero castellano, por otra, a veces más dispuesto a secundar la política eclesiástica regia, aunque se utilice el recurso al papado para evitar situaciones abusivas como, por ejemplo, el cobro de décimas sin autorización pontificia.

La monarquía corresponde a esta colaboración de los dirigentes eclesiásticos que era financiada, no se olvide, por los súbditos-fieles del reino, con la protección a aspectos que aquéllos consideraban de interés sustancial para el ejercicio de su propio poder, de su ministerio religioso, o para la dignidad de su fuero como estamento privilegiado: los reyes aseguran el cobro del diezmo eclesiástico, al menos desde tiempos de Alfonso $X$, las exenciones fiscales del clero, y dan con frecuencia mercedes a instituciones eclesiásticas específicas.

La concordia era sencilla, en definitiva, porque el poder financiero de las instituciones eclesiásticas - sobre todo de las que tenían capacidad política - era inmenso, lo que no impide que hubiera muchos sacerdotes y religiosos viviendo en el límite de la pobreza o preocupados exclusivamente de aspectos propios de la vida cristiana, pero impotentes o no 
preocupados por las contradicciones que implicaba aquel estado de cosas. ¿Cuál era la renta eclesiástica a fines de la Edad Media, procedente del diezmo eclesiástico por una parte y, por otra, de las grandes propiedades rurales y urbanas de las diversas instituciones religiosas? La única respuesta posible hoy proviene, precisamente, de cálculos a partir del importe de la décima pagada por el clero a los reyes en muchas ocasiones, puesto que se repartía por diócesis según el nivel de rentas de cada una. Se puede estimar entre 1,4 y 1,7 millones de ducados hacia 1500, incluyendo las «tercias reales" y las décimas.

\subsection{Las aristocracias ciudadanas}

Los grupos dirigentes de las ciudades de "realengo» eran el sector de la "sociedad política» dotado de una conciencia más clara de comunidad, de reino frente a rey, puesto que habían de actuar corporativamente, a través de Cortes y Hermandades, y porque a él pertenecian o, al menos, en él se representaba a la casi totalidad de los contribuyentes que sufragaban la fiscalidad monárquica, ya que clero y nobleza estaban exentos de contribuciones directas, como estamentos privilegiados, excepto en Andalucía, donde todos contribuían al "pedido" - una parte de los servicios de Cortes en época trastámara - debido a las especiales necesidades de defensa de la tierra.

No es extraño que, en tales circunstancias, se haya utilizado a las Cortes como plataforma más frecuente de diálogo y reivindicación. La petición máxima se refería al control de la cuantía, cobro, gestión y gasto de los ingresos de la Corona en cuanto no formaran parte de los antiguos pechos y derechos "foreros" o "aforados". De haberse conseguido esta reivindicación, el nuevo sistema de Hacienda habría servido para sustentar una forma «pactista» de Estado, pero nunca fue así, a pesar de que en algunos momentos se dieron pasos muy importantes en este sentido, pronto desandados: 1282, 1295 a 1303, 1313 a 1325 y, por último, 1386 a 1391.

De hecho, la reivindicación obtenida de manera más habitual se limitó a conseguir que el rey no pudiera imponer "pedidos" y «monedas» 0 , hasta 1398, alcabalas, sin otorgamiento previo del servicio correspondiente por las Cortes, por ser contribuciones extraordinarias. Pero, aun así, se observa con claridad el deslizamiento de algunas de aquellas contribuciones hacia lo ordinario, que no exigía otorgamiento en cada ocasión: así había ocurrido ya con los diezmos aduaneros en época de 
Alfonso $\mathrm{X}$, a pesar de las promesas del rey, y así sucedió con las alcabalas a finales del siglo XIV. Isabel I, en el codicilo de su testamento (noviembre de 1504) se preguntaba si las alcabalas "que los reyes mis predecesores e yo avemos llevado son de calidad que se pueden perpetuar e llevar adelante con buena conciencia», y ordenaba «saber el origen que tovieren las dichas alcavalas, e del tiempo e como e quando e para qué se pusieron, e si la imposición fue temporal o perpetua, e si ovo libre consentimiento de los pueblos para se poder poner y llevar y perpetuar como tributo justo y ordinario o como temporal, o se ha extendido a más de lo que al principio fue puesto...». Por desgracia para la moribunda reina, la investigación histórica de su tiempo no estaba capacitada para responder, aunque en los años 1503 y 1504 se había hecho un notable esfuerzo de revisión de los archivos reales.

Pero todavía más importante que el deslizamiento hacia lo ordinario era la facilidad con que las Cortes otorgaban habitualmente lo que el rey pedía, a pesar de resistencias formales y más bien limitadas, porque unos eran los otorgantes y otros los contribuyentes, a medida que los "procuradores" representaban cada vez menos al «común» de los vecinos. Ni siquiera podian las Cortes, a pesar de su empeño, asegurar que los servicios que otorgaban se gastaran en aquello para lo que fueron concedidos: este descontrol muestra el grado de independencia con que actuaba el poder monárquico, a pesar de los esfuerzos realizados desde tiempos de Fernando IV, al menos. En algunos momentos del reinado de Enrique IV llegó a proyectarse la constitución de una «Diputación del Reino", lejano precedente de lo que ocurriría a finales del siglo XVI, con mucha mayor efectividad, para controlar el servicio de «millones», pero no llegó a consolidarse.

Por lo demás, esta relativa impotencia no era obstáculo para que las Cortes cumplieran una función apreciable, aunque muy reiterativa y formal, en la denuncia de todo género de defectos y abusos del sistema fiscal: parece tratarse de una actuación derivada del deber de consejo e información al rey, pero éste no se hallaba políticamente vinculado por ella, ni obligado, por lo tanto, a adoptar las soluciones propuestas por los procuradores. No obstante, la lectura de las actas de sesiones indica, en éste como en otros aspectos, el grado de tensión o cooperación entre las partes implicadas, y contribuye a que el historiador de hoy pueda tomar la medida exacta de las situaciones políticas concretas que se. producian.

Otra cuestión en la que los procuradores mostraron siempre especial interés, sobre todo antes de la época Trastámara, fue el intento de controlar el cobro de las rentas reales, al menos cuando eran ingresos de 
tipo extraordinario. En efecto, al tratarse de contribuciones directas, los concejos habian de facilitar empadronadores y "cogedores", de modo que, ¿por qué no sustituir el arrendamiento del servicio por la gestión directa y la entrega a la Corona de la cantidad global acordada? Habría en ello un beneficio doble: económico, pues los concejos o bien gravarían menos a los contribuyentes, o bien podrían reservarse la parte que de otra manera iría a parar a los arrendadores como beneficio; político, porque se vinculaba a la monarquia a procedimientos recaudatorios controlados por los concejos, lo que podía ser el primer paso para conseguir también una intervención en otras fases y aspectos de la gestión hacendística. Por eso, seguramente, los reyes aceptaron muy pocas veces este procedimiento, a pesar de las resistencias al pago de servicios que surgen en diversos momentos y que alcanzan carácter habitual en Galicia, como hemos indicado o, en menor medida, en Murcia.

Utilizando los documentos del archivo municipal de esta ciudad ha mostrado D. Menjot cómo, bajo los trastámara, de los «servicios» se arrendaba sólo las «monedas», mientras que el o los «pedidos» los entregaba directamente el concejo al rey, repartiéndolos directamente entre los vecinos, de modo que, aun cuando hubiera arrendadores, la intervención de las autoridades municipales era muy fuerte: empadronar, recoger el dinero, dar a los arrendadores lo correspondiente a las «monedas» -pues éstos habían pagado ya su precio de arrendamiento al rey- y a los recaudadores reales el importe del "pedido"... En el transcurso de aquellas operaciones, se podía acentuar el carácter regresivo de ambas contribuciones, menos gravosas cuanto mayor era la fortuna del contribuyente, reconocer $\mathrm{o}$, por el contrario, denegar exenciones de pago, negociar préstamos o anticipos, o establecer contribuciones locales indirectas que sustituyeran a las directas («sisas»), o «derramas», de modo que el margen de maniobra de las aristocracias locales era bastante grande y no siempre se ejercía en favor del vecindario en su conjunto.

La condición de exenio de impuestos directos era muy buscada, en aquellas circunstancias. Lo estaban, como privilegiados, la nobleza y el clero; también los caballeros "de cuantía", siempre que mantuvieran su equipo y obligaciones militares, los vasallos del rey que recibian sueldo o «acostamiento» de él, y diversos oficiales reales (monteros, monederos, obreros de las atarazanas, monteros, ballesteros del rey). También estaban exentos en algunas plazas los vecinos que vivían en su castillo o alcázar, o bien dentro de los muros, o los nuevos vecinos durante algunos años, para ayudar a su asentamiento. Y, en ocasiones, había cupos de "excusados" del pago de servicios en algunos lugares, cuya población se quería favorecer. Igualmente eran exentos los habitantes de 
castillos de la frontera con Granada. Pero no es cuestión de detallar ahora estas «franquezas", reales o municipales, pues eran muy limitadas y estaban sujetas siempre a revisiones y pesquisas rigurosas por parte de las autoridades locales.

Otro punto de vista para comprender mejor la gran desigualdad del reparto de poder político entre la Corona y las ciudades castellanas de realengo es el estudio de las fiscalidades municipales, siempre insuficientes y deficitarias en sus ingresos ordinarios, teniendo en cuenta que el cobro de otros extraordinarios tenía que ser autorizado siempre por los reyes. Cada caso presenta peculiaridades, por lo que es difícil establecer conclusiones comunes, aparte de las generalidades ya indicadas, pero se impone la idea de la exigüidad habitual de recursos. Sevilla, con más de 40.000 h. en la ciudad y al menos 90.000 en su territorio, contaba sólo con 2,2 a 3,3 millones de maravedíes como ingresos ordinarios anuales a finales del siglo $\mathrm{xV}$, o bien de 5,3 a 7 millones incluyendo los extraordinarios (14.000 a 18.600 ducados), Córdoba oscilaba entre 1.800 y 3.000 , lo mismo que Jaén, por aquellos años, mientras que Jerez no superaba los 2.000 en el año 1518, ni Murcia los 3.000 en 1407, incluyendo recursos extraordinarios. Sin embargo, es necesario todavía hacer muchos estudios sobre fiscalidades locales para obtener conclusiones más sólidas.

Nunca, en definitiva, llegó el reino a través de sus representantes estamentales a tener conocimiento del total de los ingresos de la Hacienda regia, ni controló su gestión, ni a los cargos e instituciones que la realizaban, ni el gasto y sus cuentas, de modo que, aun cediendo o pactando a veces en puntos concretos, la realeza conservó su total libertad juridica y política en materia hacendística y, en tales circunstancias, aunque sujeta siempre a las realidades sociales y económicas de base, contó con la nueva fiscalidad como medio fundamental para el desarrollo de un Estado de tipo absolutista en la Corona de Castilla que fue, en definitiva, el núcleo de la Monarquía Hispánica a partir de los Reyes Católicos. 


\section{APENDICE}

\section{Nota sobre equivalencias monetarias}

La "dobla» pesa $4,60 \mathrm{~g}$ y tiene una ley de 23,75 quilates de oro. Es la monera de oro más acuñada y utilizada en Castilla desde tiempos de Alfonso $X$ hasta finales del siglo $X V$.

El «ducado» apenas circuló en Castilla antes del siglo XV, como tampoco el florín de Florencia. Estimando que el ducado es una moneda de $3,50 \mathrm{~g}$ de peso y ley en oro de 23,75 quilates, una dobla equivale a 1.314 ducados, aunque el cambio legal en el siglo $x v$, hasta 1480 , fue un poco superior $(1 \times 1,42)$.

En las tablas de ingresos hacendísticos hago los cálculos de equivalencia de maravedíes a doblas hasta 1400 , más el equivalente imaginario en ducados. En el siglo XV, como se conoce ya el curso legal del ducado con mucha frecuencia, es posible hacer la conversión de marevedíes a ducados directamente.

El «real» de plata pesa $3,48 \mathrm{~g}$ y tiene una ley de 11 dineros y 6 granos, hasta que, en 1497 , se acuña con $3,43 \mathrm{~g}$ y ley de 11 dineros y 4 granos. Utilizo siempre su equivalencia legal con el maravedí: Pedro I la fijó en 3 maravedies cuando acuñó el real por primera vez, y fue subiendo hasta $34 \mathrm{mrs}$. en 1497.

La «ratio» entre oro y plata se ha modificado a lo largo de la Baja Edad Media pero sólo se puede estimar aproximadamente, a través de la comparación entre el curso legal de las monedas de uno y otro metal, conociendo su peso en metal fino. Sobre esta base, propongo la siguiente evaluación:

\begin{tabular}{cl}
\hline AÑO & \\
\hline 1268 & $1 \times 9,85$ \\
1291 & $1 \times 13$ \\
1310 & $1 \times 12,5$ \\
1355 & $1 \times 8,82$ \\
1406 & $1 \times 9,27$ \\
1429 & $1 \times 9,06$ \\
1444 & $1 \times 11,93$ \\
1453 & $1 \times 9,94$ \\
1465 & $1 \times 11,42$ \\
1474 & $1 \times 11,20$ \\
1480 & $1 \times 12$ \\
1497 & $1 \times 10,70$ \\
\hline
\end{tabular}


Fiscalidad regia y génesis del Estado en la Corona de Castilla (1252-1504)

2. Evolución del valor del maravedí, en plata

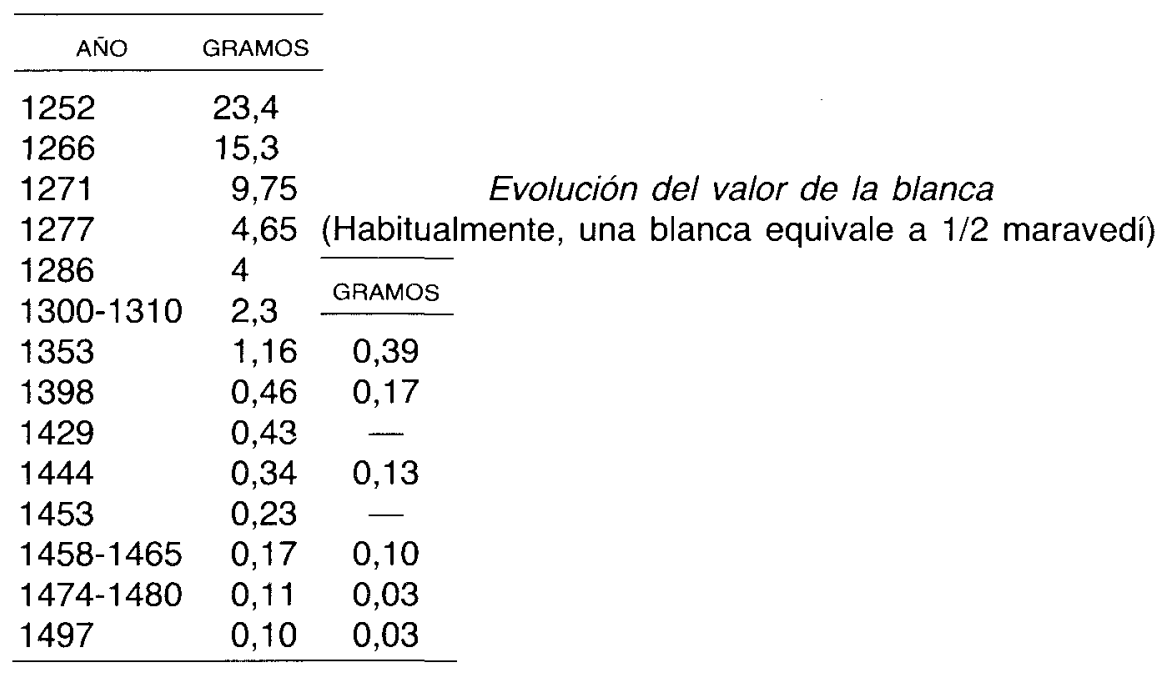

3. Evolución del valor de la dobla de oro, en maravedíes

\begin{tabular}{cc}
\hline AÑO & GRAMOS \\
\hline 1268 & 3 \\
1291 & 15 \\
1310 & 25 \\
1340 & 35 \\
1391 & 37 \\
1398 & 95 \\
1455 & 210 \\
1461 & 280 \\
1465 & 300 \\
1471 & 400 \\
1475 & 435 \\
1483 & 485 \\
1497 & 485 \\
\hline
\end{tabular}


4. Tipología de los ingresos

1. «Pechos» y «derechos" tradicionales:

- Martiniega, marzazga, infurción.

- Yantar, conducho, hospedaje.

- Fonsadera, galeras, acémilas.

- Botín y parias.

2. Regalías:

- Minas. Salinas y alfolíes de sal.

- Moneda.

- Derechos de justicia y cancillería. Escribanías públicas.

- Bienes mostrencos y de abintestato.

- Capitaciones de judíos y mudéjares.

3. Impuestos indirectos. Potestad sobre tráficos y transacciones:

- Portazgos.

- Aduanas. Su diversidad: almojarifazgos y diezmos. "Cosas vedadas".

- Sisas y alcabalas.

- Servicio de ganados trashumantes. Montazgo.

4. Contribuciones directas:

- Pedidos y monedas foreras.

- Servicios no foreros otorgados por las Cortes.

5. Transferencias de la fiscalidad eclesiástica:

- Tercias reales.

- Subsidios y décimas del clero.

- Contribuciones extraordinarias del clero.

- Bula de cruzada.

- Maestrazgos de Órdenes Militares.

- Inquisición.

6. Otros recursos extraordinarios. Empréstitos y repartos. 
5. Servicios de cortes. 1269 a 1367

Año

1269

1274

1275

1277

1282

1283

1285

1288

1297

1302

1305

1307

1309

1310

1312

1314

1315

1316

1317

1318

1320

1321

1324

1325

1329

1332

1333

1336

1337

1338

$1339-40$

1342

1343

1345

Servicios otorgados

Seis (dos por año). Cada uno como una «moneda». Dos monedas.

Dos «monedas» en 1276. Una en 1277.

Una moneda anual, durante toda la vida de Alfonso $X$.

Moneda forera y una «ayuda» al infante Don Sancho.

Una moneda.

Dos monedas. Fonsadera.

Una moneda anual, durante un período de 10 años.

Requisa o «manlieva» hecha por la regente María de Molina.

Cinco monedas.

Cinco monedas

Cinco monedas

Ocho monedas

Cinco monedas. $Y$ tres anuales, en lo sucesivo.

Moneda forera, y cinco monedas.

Moneda forera, y cinco monedas.

Tres o cinco monedas.

Un servicio en Andalucía de un milión de maravedíes.

Cinco monedas

Moneda forera, y cinco monedas.

Seis o siete monedas.

Cinco monedas, en la zona de una tutoría de Alfonso XI.

Cinco monedas, en la zona de una tutoría.

Moneda forera, y cinco monedas.

Cuatro "servicios y monedas"

Servicio para la coronación y toma de caballería de Alfonso XI.

Alcabala del 1 por 100 en Andalucía y Murcia.

Moneda forera, y cinco monedas.

Cuatro «servicios» en tierra de la Orden de Santiago.

Alcabala en Andalucía y Murcia, como en 1333.

Servicios, para pago de sueldos militares.

Alcabala general por tres años, del 3,33 por 100 .

Dos monedas

Alcabala del 3,33 por 100 , por seis años. Renovada en 1348. 
1349 Dos monedas y dos «servicios» (¿alcabalas?).

1351 Una moneda.

$1352 \quad$ Una moneda

1353 Una moneda

$1359 \quad$ Cinco servicios, y monedas ${ }^{1}$.

1361 Servicios y monedas.

1363 Servicios y monedas.

1365 Servicios y monedas.

1367 Cinco servicios, dos monedas, y alcabala.

1 Es muy posible que en estos años la expresión «servicios» se refiera a las alcabalas, o bien a la totalidad de lo otorgado, mientras que «monedas» hace referencia sólo a la parte cobrada de esta manera, por vía de «moneda". 
Fiscalidad regia y génesis del Estado en la Corona de Castilla (1252-1504)

6. Ingresos totales, ordinarios y extraordinarios, 1369 a 1406

\begin{tabular}{|c|c|c|c|}
\hline AÑO & MARAVEDÍES & EN DOBLAS & EN DUCADOS \\
\hline 1369 & 29.000 .000 & 828.571 & $1.077 .000^{(1)}$ \\
\hline 1370 & 32.300 .000 & 922.857 & 1.199 .000 \\
\hline 1371 & 33.750 .000 & 964.285 & 1.253 .000 \\
\hline 1372 & 46.300 .000 & 1.322 .857 & 1.719 .000 \\
\hline 1373 & 31.200 .000 & 891.428 & 1.159 .000 \\
\hline 1374 & 37.500 .000 & 1.071 .428 & 1.393 .000 \\
\hline 1375 & 41.200 .000 & 1.177 .142 & 1.530 .000 \\
\hline 1376 & 38.000 .000 & 1.085 .714 & 1.411 .000 \\
\hline 1377 & 38.000 .000 & 1.085 .714 & 1.411 .000 \\
\hline 1378 & 38.000 .000 & 1.085 .714 & 1.411 .000 \\
\hline 1379 & 38.000 .000 & 1.085 .714 & 1.411 .000 \\
\hline 1380 & 38.000 .000 & 1.085 .714 & 1.411 .000 \\
\hline 1381 & 44.000 .000 & 1.189 .000 & 1.545 .000 \\
\hline 1382 & 44.000 .000 & 1.189 .000 & 1.545 .000 \\
\hline 1383 & 44.000 .000 & 1.189 .000 & 1.545 .000 \\
\hline 1384 & 47.000 .000 & 1.270 .000 & $1.651 .000^{(2)}$ \\
\hline 1385 & 47.000 .000 & 1.270 .000 & $1.651 .000^{(2)}$ \\
\hline 1386 & 44.000 .000 & 1.190 .000 & $1.547 .000^{(3)}$ \\
\hline 1387 & 53.000 .000 & 1.432 .000 & 1.861 .600 \\
\hline 1388 & 45.200 .000 & 1.221 .621 & 1.588 .000 \\
\hline 1389 & 36.000 .000 & 973.000 & 1.265 .000 \\
\hline 1390 & 35.000 .000 & 946.000 & 1.230 .000 \\
\hline 1391 & 24.000 .000 & 648.648 & 843.000 \\
\hline 1392 & 24.000 .000 & 648.648 & 843.000 \\
\hline 1393 & 24.000 .000 & 648.648 & 843.000 \\
\hline 1394 & 28.000 .000 & 756.000 & 983.000 \\
\hline 1395 & 28.000 .000 & 756.000 & 983.000 \\
\hline 1396 & 43.000 .000 & 1.162 .000 & 1.510 .000 \\
\hline 1398 * & 41.000 .000 & 1.108 .000 & 1.440 .000 \\
\hline 1401 & 91.500 .000 & 963.158 & 1.307 .143 \\
\hline 1406 & 60.000 .000 & 631.578 & 857.142 \\
\hline
\end{tabular}

(1) Quiebra de moneda.

(2) Más empréstitos, «plata» de la vajilla real, «llevas de pan», «galeotes»...

(3) Quiebra de moneda, empréstitos y cesiones en señorío.

* En 1398 hubo una devaluación monetaria: un maravedí nuevo salía la mitad de uno antiguo. Pero la dobla pasó a 37 a $95 \mathrm{mrs}$. de valor y el real de 3 a $7,5 \mathrm{mrs}$. 


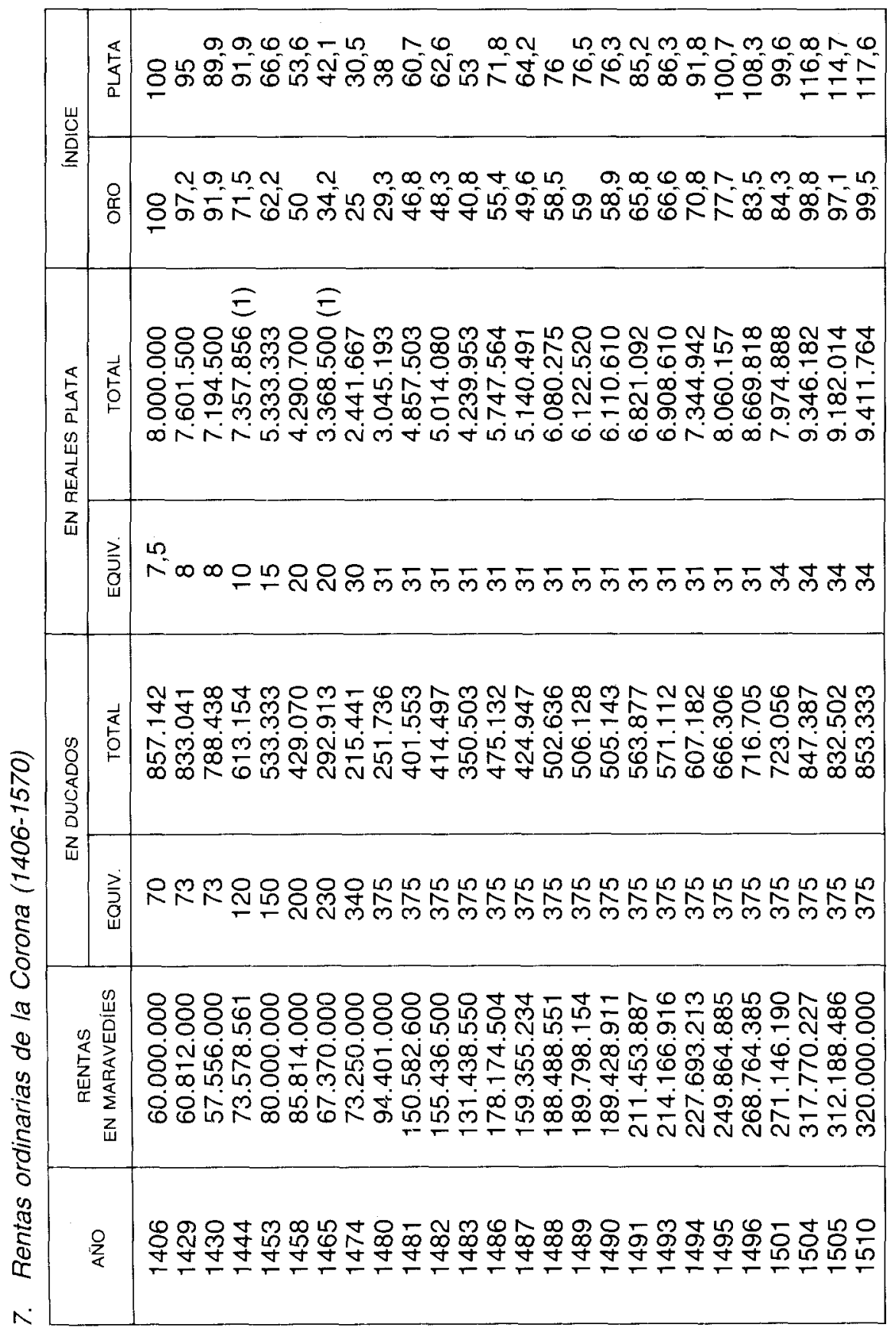


8. Alcabalas $y$ tercias

\begin{tabular}{ccc}
\hline \multicolumn{3}{c}{$\begin{array}{c}\text { ANNO DEL TOTAL DE } \\
\text { RENTAS } \\
\text { ORDINARIAS }\end{array}$} \\
\multicolumn{3}{c}{ (alcabalas 76,8 tercias 5) } \\
1429 & 82 & (alcabalas 80 tercias 8,46$)$ \\
1430 & 79 & \\
1444 & 88,4 & \\
1453 & 81,9 & \\
1458 & 79,2 & \\
1465 & 77,3 & media (sin los dos extremos) 80,52 por 100
\end{tabular}

\section{Aduanas}

AÑO CANTIDAD TOTAL ESTIMADA \% DEL TOTAL RENTAS ORDINARIAS mrs.

\begin{tabular}{lrr|r}
1429 & 6.971 .967 & 11,6 \\
1444 & 7.793 .216 & 10,6 & \\
1453 & 9.823 .701 & 12,2 & Media \\
1458 & 10.940 .844 & 12,8 & 12,2 \\
1465 & 13.568 .991 & 20,2 & \\
& & & \\
1481 & 8.438 .000 & 5,6 & \\
1486 & 7.810 .000 & 4,4 & \\
1491 & 8.753 .500 & 4,15 & Media \\
1496 & 11.036 .500 & 4,11 & 4,5 \\
1501 & 12.951 .500 & 4,77 & \\
1504 & 15.379 .000 & 4,84 & \\
& & &
\end{tabular}

(Entre 1481 Y 1504 se ha enajenado los diezmos de la mar de Castilla, no hay datos de los de Galicia y Asturias, ni de Cartagena y Granada, no parece que haya aduana en la frontera de Valencia. Sumando todo esto, se deduce que el descenso de porcentaje es más aparente que real: o cobraban las aduanas otros poderes, o no se cobraban, lo que hace lógico este descenso de porcentaje). 
10. Salinas

AÑO $\%$ DEL TOTAL DE RENTAS
ORDINARIAS

$1429 \quad 1.935 .411 \mathrm{mrs} . \quad 3,2$

$1444 \quad 2.595 .043 \mathrm{mrs} . \quad 3,5$

$\begin{array}{ll}1453 & 2.835 .938 \mathrm{mrs} . \quad 3,5\end{array}$

$\begin{array}{ll}1458 & 3.404 .234 \mathrm{mrs} . \quad 3,9\end{array}$

$1465 \quad 3.778 .400$ mrs. 5,6 máximo

$1491 \quad 5.231 .761 \mathrm{mrs} . \quad 2,5$ sin Galicia ni otras menores

1504 6.996.593 mrs. 2,2 sin Galicia ni otras menores

\section{Servicio y montazgo}

$\left.\begin{array}{lrl}1429 & 834.000 \mathrm{mrs} . & 1,4 \\ 1444 & 1.616 .975 \mathrm{mrs} . & 2,2 \\ 1453 & 2.440 .683 \mathrm{mrs} . & 3 \\ 1458 & 1.300 .000 \mathrm{mrs} . & 1,5 \\ 1465 & 2.062 .000 \mathrm{mrs} . & 3\end{array}\right\} \begin{gathered}\text { Media } \\ 2,42 \\ 1481\end{gathered}$


Fiscalidad regia y génesis del Estado en la Corona de Castilla (1252-1504)

12. Ferrerias $y$ «Fueros derechos»

\begin{tabular}{|c|c|c|}
\hline \multicolumn{3}{|c|}{ Ferrerías } \\
\hline 1429 & $305.000 \mathrm{mrs}$. & \multirow{4}{*}{$\begin{array}{l}2,1 \text { en } 1429 \\
0,9 \text { en } 1481\end{array}$} \\
\hline 1481 & $392.000 \mathrm{mrs}$. & \\
\hline \multicolumn{2}{|c|}{ Pedidos y "fueros derechos" } & \\
\hline $\begin{array}{l}1429 \\
\text { sigue }\end{array}$ & $1.000 .000 \mathrm{mrs}$ & \\
\hline
\end{tabular}

El resto de ingresos menores, algunos eventuales, no proporcionarían más allá de 0,5 por 100 , en el mejor de los casos. Frecuentes enajenaciones.

Cuando hay parias, son un promedio de 12.000 doblas $(\times 1,4=$ 18.200 ducados). En época de Juan II esto representa un 2 a 3 por 100 con respecto al total de los ingresos ordinarios.

13. Contribuciones especiales de judíos y mudéjares

Cabeza de pecho (último tercio siglo XIV)

Mrs. Duc.

Judios $\quad 381.727 \quad 10.316$

Mudéjares $\quad 24.200 \quad 654$

Servicio y medio servicio (1430 a final siglo XV)

$\begin{array}{llll} & \text { Mrs. } & \text { Duc. } & \text { Duc. } \\ \text { Judíos } & 450.000 & 6.164 \text { en } 1430 & 1.200 \text { en } 1480 \\ \text { Mudéjares } & 150.000 & 2.050 \text { en } 1430 & 400 \text { en } 1480\end{array}$

14. Derechos de acuñación en casas de moneda Mrs. Duc.

1461-1462 $\quad 6.907 .80030 .000 \quad(15.000$ al año $)$. 
15. Moneda forera

Años en los que hay constancia de su cobro

Año Mrs. Duc.

$\begin{array}{lll}1434 & 4.000 .000 & 54.794 \\ 1440 & 4.000 .000 & 33.333 \\ 1458 & 4.000 .000 & 20.000 \\ 1464 & 4.000 .000 & 17.500 \\ 1482 & 4.600 .000 & 12.666 \\ 1488 & 5.600 .000 & 15.000 \\ 1494 & 6.200 .000 & 16.500\end{array}$

16. Rentas del reino de Granada Mrs. Duc.

\begin{tabular}{|c|c|c|c|}
\hline 1494 & 26.742 .407 & 71.313 & $\begin{array}{l}11,77 \text { (por encima del } 100 \mathrm{de} \\
\text { rentas ordinarias) }\end{array}$ \\
\hline 149 & 28.811 .691 & 76.831 & 10,75 \\
\hline 150 & 36.344 .898 & 96.919 & 11,46 \\
\hline 150 & 29.032 .404 & 77.419 & 9,30 \\
\hline
\end{tabular}

17. «Servicios» extraordinarios Granada

Duc.

$\left.\begin{array}{ll}1497 & 20.000 \\ 1499 & 20.000\end{array}\right\} 2,7 \%$ r.o.

$150420.000 \quad(7.500 .000) 2,3 \%$ r.o.

(añadir la «farda» para la vigilancia costera de 1.618 .000 mrs. en 1501 y 4.314 ducados). 
Fiscalidad regia y génesis del Estado en la Corona de Castilla (1252-1504)

18. "Servicios" de Cortes, 1407 a 1477

$\begin{array}{ccc}\text { PERIODO DE COBRO } & \text { CANTIDAD TOTAL EN } \\ \text { MRS. } & \text { CANTIDAD TOTAL EN } & \text { CANTIDAD ANUAL } \\ \text { DUCADOS } & \end{array}$

$\begin{array}{lrrr}1407 \text { a } 1411 & 218.000 .000 & 3.114 .285 & 622.857 \\ 1419 \text { a } 1422 & 70.000 .000 & 1.000 .000 & 250.000 \\ 1425-1426 & 38.000 .000 & 520.547 & 260.274 \\ 1429 \text { a } 1443 & 528.000 .000 & 6.370 .000 & 424.666 \\ 1444 \text { a } 1454 & 414.500 .000 & 3.070 .000 & 279.124 \\ 1455 & 71.000 .000 & 473.333 & 473.333 \\ 1457-1458 & 72.000 .000 & 360.000 & 180.000 \\ 1462-1463 & 86.500 .000 & 432.000 & 216.000 \\ 1469-1470 & 93.000 .000 & 273.529 & 136.764 \\ 1473-1474 & 123.000 .000 & 361.764 & 180.882 \\ 1476-1477 & 162.000 .000 & 443.835 & 221.917\end{array}$

19. "Contribuciones» de la Hermandad, 1478 a 1498
A) Ordinaria
1478 a 1485
124.600 .000
332.266
47.466
1486 a 1498
436.000 .000
1.162 .666
89.436
B) Extraordinaria
1482 a 1485
44.000 .000
117.333
29.333
1487 a 1491
217.125 .000
579.000
115.800

20. «Servicios» de Cortes, 1500 a 1517

$\begin{array}{llrr}1500 \text { a } 1502 & 150.000 .000 & 400.000 & 133.133 \\ 1503-1504 & 200.000 .000 & 533.333 & 266.666 \\ 1507 \text { a } 1509 & 105.000 .000 & 280.000 & 93.333 \\ 1510 \text { a } 1517 & 409.000 .000 & 1.090 .666 & 136.333\end{array}$


21. Cruzada y subsidio eclesiástico

\begin{tabular}{|c|c|c|c|}
\hline & & $\begin{array}{l}\text { CANTIDAD } \\
\text { TOTAL EN } \\
\text { DUCADOS }\end{array}$ & $\begin{array}{l}\text { CANTIDAD } \\
\text { ANUAL }\end{array}$ \\
\hline 1431 & $\begin{array}{l}100.000 \text { florines de Aragón } \\
\text { No hay noticia del importe de cru- } \\
\text { zada }\end{array}$ & & 74.000 \\
\hline 1457 a 1460 & $\begin{array}{l}100.000 .000 \text { cruzada (D. Valera) } \\
23.000 .000 \text { subsidio }\end{array}$ & 615.000 & 153.750 \\
\hline 1484 a 1492 & $\begin{array}{l}500.000 .000 \text { cruzada } \\
178.875 .000 \text { subsidio }\end{array}$ & 1.808 .000 & 200.888 \\
\hline 1495 a 1503 & $\begin{array}{l}170.000 .000 \text { cruzada } \\
139.726 .000 \text { subsidio }\end{array}$ & 826.666 & 91.850 \\
\hline
\end{tabular}

Es sólo lo contenido en la cuenta del tesorero Morales.

22. Recursos extraordinarios nuevos, en época de los Reyes Católicos

\begin{tabular}{ccc} 
mrs. duc. & duc/año \\
\hline
\end{tabular}

1. Contribución de judios y mudéjares para la guerra de Granada

$\begin{array}{llrr}1482-1491 \text { Judíos } & 51.410 .000 & 137.093 & 13.709 \\ 1482-1501 \text { Mudéjares } & 41.000 .000 & 109.333 & 5.466\end{array}$

2. Venta de «juros»

1489-1490

$100.000 .000 \quad 266.666$

$\begin{array}{llll}1495 \text { a } 1503 & 203.251 .000 & 542.000 & 6.022,2\end{array}$

3. Otros ingresos: "extraordinario", "saca de pan", ventas de esclavos granadinos, empréstitos

$\begin{array}{llll}1495-1503 & 354.500 .000 & 945.333 & 105.037\end{array}$

4. Inquisición (lo que "finca", tras su gasto propio)

$\begin{array}{llll}1495-1503 & 63.000 .000 & 168.000 & 1.866,6\end{array}$

5. Maestrazgos de Órdenes Militares (el «finca»)

$1504 \quad 16.000 .000 \quad 42.666$


23. Apuntamientos de gastos. Años 1429 y 1504

Año 1429

(en miles de maravedies)

Ingresos (cargo)

60.800

Gastos (data):

Situado

15.986

Prometidos y suspensiones

Tierras de vasallos

13.664

Tenencia de castillos

3.885

Tenencia y mantenimiento de castillos fronteros con Granada

8.271

Raciones

4.669

Quitaciones

2.674

Cámara, despensa, aposentadores

2.143

Tesorero del rey

Ayudas de costa

0,987

Mantenimientos

0,224

Obras en alcázares reales

0,150

Año 1504

(en miles de maravedíes)

Ingresos

315.667

Gastos:

Situado

Situado por préstamos

86.059

Prometidos y suspensiones

Guardas Reales, artillería, "acostamientos» de vasallos, te-

18.660

10.811 nencia de fortalezas

104.356

Casas del Rey y de la Reina

Mantenimiento a personas de la Corte

26.517

9.604

Consejo Real

3.720

Mayordomo y Contadores Mayores

2.055

Físicos y boticarios

0,825

Aposentadores

0,470

Continuos

5.000

Administración territorial

0,740

Ayudas de costa y mercedes

5.477

Limosnas

1.000

Obras

3.600

Otras libranzas sin especificar

28.000 
24. Gastos extraordinarios: 1495 a 1504

En época de los Reyes Católicos, las necesidades extraordinarias seguian siendo del mismo tipo, pero de mayor tamaño y más continuas. Entre 1495 y 1504 el tesorero Alonso de Morales administró la mayor parte de los recursos extraordinarios. He aquí en qué gastó un total de 1.730 millones de maravedíes:

Gastos de guerra y de tipo militar

Compras de trigo para tropas

Embajadores y correos

Dotes y gastos de casamiento de las infantas

Amortización de préstamos

Mercedes, limosnas, mantenimientos, ayudas de costa, quitaciones

Cámara de la reina

Gastos en Yndias

Otros

Gastos justificados 
Fiscalidad regia y génesis del Estado en la Corona de Castilla (1252-1504)

25. Corona de Castilla: regiones y zonas tributarias

\begin{tabular}{|c|c|c|c|c|c|c|}
\hline ZONAS & 1429 & 1451 & 1465 & 1482 & 1493 & 1504 \\
\hline Castilla Norte & 16,3 & 17,7 & 17,7 & 11,5 & 10,8 & 9,3 \\
\hline Castilla Este & 9,3 & 9,2 & 7,7 & 7,5 & 8,7 & 7,5 \\
\hline Castilla Sur & 12,1 & 10 & 8,7 & 8,6 & 9,2 & 8,9 \\
\hline León & 9,6 & 7,4 & 6,6 & 6,5 & 7,1 & 7,2 \\
\hline Asturias & 1,8 & 1,5 & 1,6 & 1,6 & 2 & 1,8 \\
\hline Total Castilla-León & 49,1 & 45,8 & 42,2 & 35,8 & 37,8 & 34,7 \\
\hline Galicia & 4,8 & 5,2 & 4,2 & 4,3 & 5,1 & 5,8 \\
\hline Toledo & 11,2 & 11,5 & 11,8 & 9,1 & 10 & 10 \\
\hline Cuenca & 5,1 & 4,4 & 4 & 4,5 & 6 & 5,5 \\
\hline Extremadura & 4,2 & 4 & 5,1 & 2,9 & 3,8 & 3,4 \\
\hline Órdenes Militares & & & & 10,2 & 10,3 & 9,8 \\
\hline Servicio y Montazgo & 1,3 & 2,4 & 2,3 & 3 & 2,7 & 2,1 \\
\hline Total Castilla N. y Extremadura & 22 & 22,2 & 23,3 & 29,8 & 32,8 & 30,8 \\
\hline Sevilla & 15,4 & 16,2 & 19,8 & 18,9 & 14,3 & 17,2 \\
\hline Córdoba & 4,1 & 5,8 & 7,5 & 7,3 & 4,7 & 5,2 \\
\hline Jaén & 2,8 & 3 & 2,4 & 2,9 & 4 & 5,1 \\
\hline Total Andalucía & 22,3 & 25 & 29,7 & 29 & 23 & 27,5 \\
\hline $\begin{array}{l}\text { Murcia } \\
\text { Reino de Granada }\end{array}$ & 1,7 & 1,7 & 1,1 & 1,4 & 1,4 & $\begin{array}{r}1,1 \\
(11,6)\end{array}$ \\
\hline
\end{tabular}

Otro punto de vista es el reparto territorial de los servicios de Cortes. En 1500, cuando habían vuelto a cobrarse también en los señoríos, era éste:

$\begin{array}{lrlrlr}\text { Galicia } & 11,32 & \text { Castilla-León } & 39,07 & \text { Extremadura } & 7,82 \\ \text { Orla cantábrica } & 0,82 & \text { Meseta S.-Murcia } & 17,55 & \text { Andalucía } & 23,40\end{array}$


CORONA DE CASTILLA:

REGIONES Y ZONAS TRIBUTARIAS

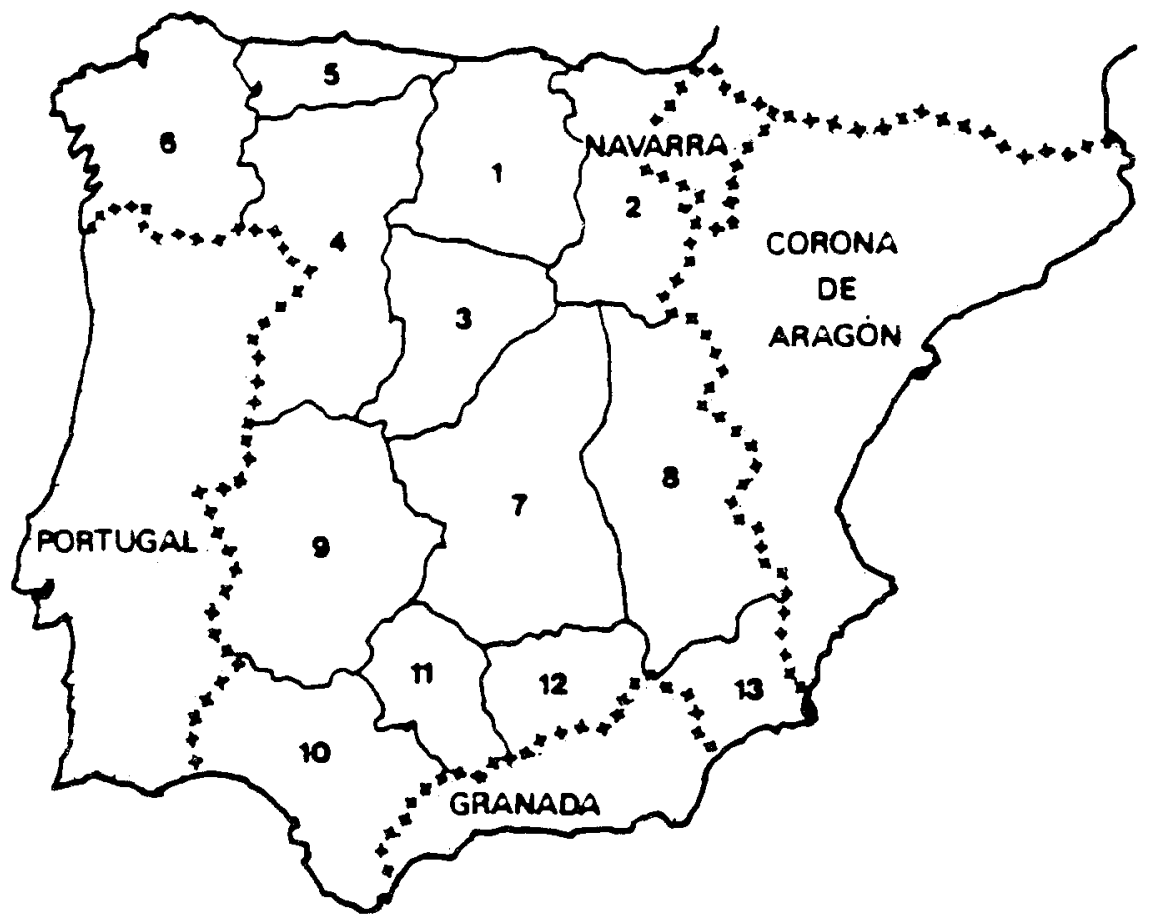

1 CASTILLA NORTE

2 CASTILLA ESTE

3 CASTILLA CENTRO-SUR

4 LEON

5 ASTURIAS

6 GALICIA

7 TOLEDO

8 CUENCA

9 EXTREMADURA

10 SEVILLA

11 CORDOBA

12 JAEN

13 MURCIA 


\section{BIBLIOGRAFÍA}

Esta conferencia se ha elaborado partiendo de mis investigaciones anteriores, especialmente las siguientes:

Fiscalidad y poder real en Castilla. 1252-1369. Madrid (en prensa). Algunos aspectos de este trabajo han sido publicados en "Las transformaciones de la fiscalidad regia castellano-leonesa en la segunda mitad del siglo XIII (1252-1312)», Historia de la Hacienda Española (Épocas Antigua y Medieval). Madrid, Instituto de Estudios Fiscales, 1982, págs. 319-406, y "De la "Reconquista" à la fiscalité d'État Laus la Couronne de Castille (1268-1368), Génèse de l'État moderne. Prélèvement et redistribution. Paris, CNRS, 1987, págs. 35-51.

"Cortes de Castilla y León y fiscalidad regia (1369-1429)", Las Cortes de Castilla y León en la Edad Media. Valladolid, Cortes de Castilla y León, 1988, I, págs. 289-373.

La Hacienda Real de Castilla en el siglo xv. La Laguna de Tenerife, Universidad, 1973, 383 páginas.

El siglo XV en Castilla. Fuentes de renta y politica fiscal. Barcelona, Ariel, 1982, 212 páginas. En especial los artículos titulados: "Para una imagen de Castilla (1429-1504)», «Los judíos castellanos del siglo XV en el arrendamiento de impuestos reales», «Rentas condales en Plasencia (1454-1488)", "Renta eclesiástica en la Castilla del siglo XV».

"Las ferias de Castilla. Siglos XII a XV», Cuadernos de Historia de España (Buenos Aires), LXVII-LXVIII (1982), págs. 269-347.

«La política monetaria en la Corona de Castilla, 1369-1497», En la España Medieval, 11 (1988), págs. 79-123.

"El cargo de Diego Arias Dávila en 1462", Espacio, Tiempo y Forma. Universidad Nacional de Educación a Distancia (Madrid), Serie III, H. ${ }^{a}$ Medieval n. ${ }^{\circ}$, (1989), págs. 271-293. 
«Fiscalidad regia y sector terciario en la Andalucía bajomedieval», // Coloquio de Historia Medieval Andaluza. Sevilla, Diputación Provincial, 1982, pág. 7-38.

"Las alcabalas de Sevilla y su reino en 1399 ", Estudios en Homenaje a Don Claudio Sánchez-Albornoz en sus 90 años. Universidad de Buenos Aires, IV, 1986, págs. 195-214.

"Los propios de Sevilla (1486-1502)", en Los mudéjares de Castilla y otros estudios de historia medieval andaluza. Granada, Universidad, 1989, págs. 313-346.

"La gestión de la Hacienda regia en la Corona de Castilla (1252-1369)», Hacienda Pública Española (Madrid), 108-109 (1987), págs. 15-34.

Además, son de gran importancia los trabajos de algunos otros investigadores, entre los que he manejado éstos:

Mackay, Angus, Money, prices and politics in Fifteenth-Century Castile. Londres, Royal Historical Society, 1981, 184 páginas.

- "Las Cortes y la historia monetaria, c. 1350-c. 1474», Las Cortes de Castilla y León en la Edad Media. Valladolid, Cortes de Castilla y León, 1988, I, págs. 375-426.

- «Hacienda y sociedad en la Castilla bajomedieval», Estado, Hacienda y Sociedad en la Historia de España. Universidad de Valladolid, 1989, págs. 45-78.

MENJOT, Denis, Fiscalidad y sociedad. Los murcianos y el impuesto en la Baja Edad Media, Murcia, Academia Alfonso X el Sabio, 1986, 388 páginas, en especial los artículos, "La incidencia social de la fiscalidad directa de los Trastámaras de Castilla en el siglo XIV», y, "Finanzas y fiscalidad concejiles ordinarias en Murcia en la Baja Edad Media (finales del siglo XIV-mitad del siglo XV)".

Veas Arteseros, M. ${ }^{a}$ Carmen, La Hacienda concejil murciana en el siglo xv (1423-1482). Murcia, Universidad, 1988 (tesis doctoral en microficha).

Piqueras García, M. ${ }^{a}$ Belén, Fiscalidad real y concejil en el reinado de Enrique IV: el ejemplo de Murcia (1462-1474). Cádiz, Universidad, 1988, 236 páginas.

Olivera Serrano, César, Las Cortes de Castilla y León y la crisis del reino (1445-1474). Burgos, 1986, 402 páginas.

Carretero Zamora, Juan Manuel, Cortes, monarquía, ciudades. Las Cortes de Castilla a comienzos de la época moderna (1476-1515). Madrid, Siglo XXI, 1988, 473 páginas.

Quintanilla Raso, M. ${ }^{a}$ Concepción, "Haciendas señoriales nobiliarias en el reino de Castilla a fines de la Edad Media", Historia de la Hacien- 
Fiscalidad regia y génesis del Estado en la Corona de Castilla (1252-1504)

da Española. Madrid, Instituto de Estudios Fiscales, 1982, págs. 767798.

Peinado Santaella, Rafael, "Fiscalidad señorial y tráfico comercial en Andalucía a finales de la Edad Media: notas para su estudio», II Coloquio de Historia Medieval Andaluza. Sevilla, Diputación Provincial, 1982, págs. 133-158.

TODESCA, James, "The Monetary History of Castile-Leon (ca. 1100-1300) in light of the Bourgey Hoard", American Numismatic Society Museum Notes, 33 (1988), págs. 129-203. 